\title{
Biology Online Classes During Covid-19 Pandemic in Indonesia
}

\author{
Eva Kristinawati Putri ${ }^{1{ }^{*}}$ Wisanti $^{1}$ Reni Ambarwati ${ }^{1}$ Dwi Anggorowati Rahayu ${ }^{1}$ \\ Firas Khaleyla ${ }^{1}$
}

\author{
${ }^{1}$ Biology Department, Universitas Negeri Surabaya, Indonesia \\ *Corresponding author. Email: evaputri@unesa.ac.id
}

\begin{abstract}
Indonesia reduces the spreading of COVID-19 infection by physical distancing. There is no argue that this policy affects all aspects, including education. Online learning has replaced the ordinary procedure of learning, whether we are ready or not. Organizing an online learning becomes an evitable challenge, especially for biology as a subject that has a lot of practicum. This research aimed to describe biology online learning in Indonesia during pandemic as well as describe the efforts of biology teachers to conduct an online learning. 109 biology teachers of senior high school from several regions of Indonesia were involved as respondents. Online questionnaires were conducted to collect teacher's responses using Google Forms then descriptive-quantitatively analyzed. The results indicated that biology teachers have a great intention to conduct online learning regardless of age and prior experience. Almost half of them (42\%) never managed an online learning before the pande mic. However, almost all biology teachers (95\%) managed their classes by online. Looking for free applications and study independently became the main alternative to improve their skill to manage an online learning, while some of them learned from friends. Google Classroom was the most favorite application they choose (56\%) as it is served for free by Google; meanwhile, some of them (23\%) using WhatsApp Group, the familiar social media. Biology teacher's willingness to learn should be appreciated. Starting from lack of experience, almost half of them (49\%) stated that there was no problem in organizing online classes. There were only $24 \%$ of application mastery constraints left; meanwhile others were related to student's control, mastery of subject and longer preparation time. Various learning activities were successfully managed by online classes starting from presenting materials to evaluation. Some of biology teachers (30\%) also managed practical work by online classes, whether using a virtual laboratory or simple practicum guidance to do at home. Teacher's enthusiasm responses dominated the results of the questionnaire filling for both teachers with prior experience or teachers without prior experience. It can be concluded that the efforts of biology teachers were able to realize online learning during the Covid-19 pandemic.
\end{abstract}

Keywords: Biology, Online Learning, Covid-19 Pandemic, Google Classroom, WhatsApp

\section{INTRODUCTION}

Corona virus disease changed all aspects of human life. The spreading of COVID-19 infection can be reduced by physical distancing. This physical distancing that decided by government changed Indonesian learning environment, simultaneously from face to face into online learning. As the learning environment changed and new technology become available, teachers' role also changed [1]. Teacher must act as an online educator, whether they were ready or not.
Teacher difficulties in conducting online learning are understandable. Even there is a comparative analogy between face to face teaching and online teaching with taking a trip by car or train [2]. Face to face teaching that analogized with a trip by car only need a general route planned because driver can stop along the way as long as they need. Whereas, online teaching that analogized with a trip by train need a lot of pre-planning due to the limited train stops. This limitation makes online teacher prepare their online materials and make them available from the beginning of online learning. 
Managing online learning as a substitute for face-toface learning is a challenge for Indonesian teachers. ICT infrastructure varies across Indonesia [3]. Many places, especially for rural and remote area, have not yet been covered with sufficient ICT infrastructure. Whereas, people in the big cities can enjoy broadband internet connections and hotspots. Even so, teacher can use mobile technology in their online learning management as it provides internet connections including remote and rural areas.

Pandemic, however, gives some advantages in education. Actually, Indonesian teachers were challenged by government to do some online learning before the pandemic by the term of merdeka belajar. Pandemic forced teachers to transform their conventional learning in the form of face-to-face learning into online learning in line with merdeka belajar [4]. This also in line with the vision and mission of future learning in the 4.0 industrial revolution and 5.0 community. Pandemic gives students and teachers to implement learning independently and free to explore. It also can save 577.305.660 students at risk from preprimary to high school education. In addition, pandemic accelerates the implementation of technological advanced in learning [5]. Online learning shifting the IT position from an additional facility into the main facility and included in the curriculum. From now, all learning activities are recorded as online media database.

Although it is no longer a new thing in our learning process, online learning in pandemic era different from the former trend in online learning. Blended learning becomes an alternative for our former learning process as teachers can teach their student face-to-face. However, in pandemic era, teachers are not allowed to organize face to face learning at all, especially for red zone area. This massive transformation makes organizing an online learning as an evitable challenge, even for teacher with prior experience in online learning. Thus, Biology online learning, as a subject that has a lot of practicum, becomes a very interesting study.

\section{METHOD}

The key purpose of this study was to describe biology online learning in Indonesia during pandemic era of COVID-19. Totally, 109 biology teachers of senior high school from several regions of Indonesia were involved as respondents. They were various in age (22-60 years old) and school (state schools and private schools).

An online survey technique consisting 15 questions was used to gather data about biology online learning in Indonesia. This online questionnaire was used to collect teacher's responses using Google Forms. The data obtained through an online survey were analyzed by frequency of teachers' responses and were stated in percentages.

A descriptive-quantitative analysis was used to describe respondents' profile including their prior experience which was categorized by school criteria, whether state school or private school and respondents' prior experience which was categorized by age ( $\leq 40$ years old and $>40$ years old). Biology online learning during the pandemic described from respondents' intention to conduct online learning related with their prior experience, how they improved their skill to manage an online learning, the most favourite application they choose, the difficulties they faced, the types of online learning activities they managed, and how they managed practical work by online classes.

\section{RESULTS AND DISCUSSION}

Biology online learning in Indonesia during pandemic described clearly by respondents as they vary in origin, school, and age. There were 109 biology senior high school teachers acted as respondent who came from seven provinces of Indonesia. East Java teachers dominated the respondents $(83.5 \%)$, followed by North Kalimantan $(10 \%)$ at second place. More than half of respondents were teacher at state schools $(65 \%)$, while the rest teach biology at private schools. The age of respondents was ranged within 22-60 years old.

Understanding prior experience was important to know teacher readiness in an online learning management. Supporting this issue, Hung [6] stated that teacher used their prior understanding to manage an online course. Thus, this study described teachers' prior experience in online learning based on their school and age.

Respondent' profile was calculated by percentage and classified based on their online learning prior experience and school (figure 1). This study showed that before pandemic, there was no highly differentiation prior experience between state school and private school teachers. However, teachers in private school tend to manage online learning more than
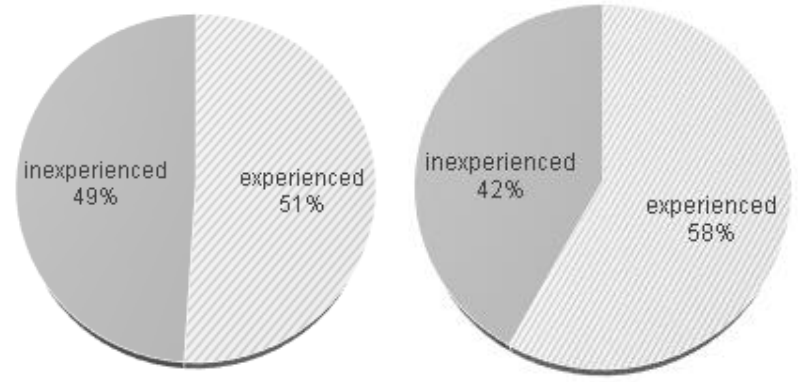

Figure 1. Charts of respondent' prior experience by school state school (left) and private school (right)

Prior experience data revealed that more than half respondents were familiar with online learning even before pandemic. For these experienced teacher, information and communication technology have contributed into their learning environment. In other words, more than half respondents were ready to manage online learning through pandemic, while the others need an extra effort to learn about how to manage an online learning. This prior experience can make 
teacher to better understand their personal characteristics, abilities and resources when conduct an online learning. Besides that, teacher can use their prior perceptions about learning environment [6]. By integrating technology in their classroom, these experienced teachers not only have knowledge about technology but also combine technology knowledge, pedagogy and content knowledge that are required in online learning management [8].

Respondents profile was analyzed by age and. prior experience (Figure 2) which showed that age did not affect teacher's prior experience in online learning management. Senior teacher motivated to manage online learning as much as their junior. Even the 60 years old teacher stated has managed an online learning before pandemic. This finding was contrary with Teo's finding [9] stated that young teacher tends to more accustomed than elder teacher in online learning management, such as computer-mediated communication in e-learning content. Young teacher considered by Teo's finding to be more familiar with communication technologies in accessing information and for interacting with others in an online learning management.

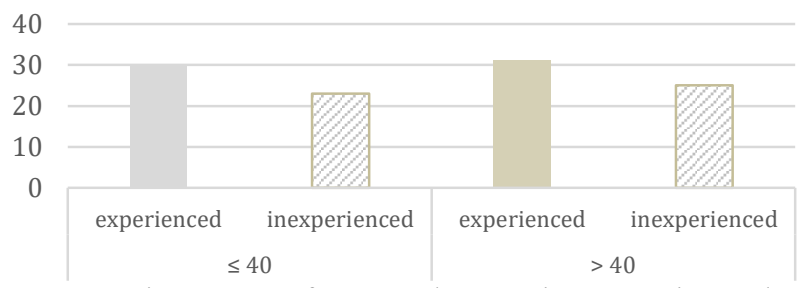

Figure 2 Histogram of respondent' prior experience by age

As there was no significant prior experience different among the respondents based on their school and age, data analysis then not categorized for respondents' school and age. Respondents' intention to conduct online learning then analyzed based on their general prior experience. This study also described how respondents improved their skill to manage an online learning, considering almost half of respondents have no prior experience in online learning management. Analyses also included the most favorite application they choose, the difficulties they faced, the types of online learning activities they managed, and how they managed practical work by online classes.

The results indicated that biology teachers have a great intention to conduct online learning during pandemic. Almost half of them (42\%) never managed an online learning before the pandemic. However, almost all biology teachers (95\%) managed their classes by online. This significant increase of biology online learning showed teacher willingness to learn in addition to governments' policy to study from home. Indonesian biology teachers put themselves as learners of online learning. This willingness is important to manage an online class successfully [10].

Indonesian biology teachers improved their skill to manage an online learning by some alternatives, such as: looking for free application and learned from friends, looking for free application and learned independently, using school facilities (school website), or hand everything over to teaching partner. The alternative way to improve online learning management skills got the same order for both experienced and inexperienced teachers (Table I).

Table 1. Comparison between experienced and inexperienced teachers in the way of improve their online learning management skills (in percentage)

\begin{tabular}{|l|c|c|}
\hline $\begin{array}{l}\text { How teacher improve } \\
\text { their online leaming } \\
\text { management skill }\end{array}$ & $\begin{array}{c}\text { experienced } \\
\text { teachers }\end{array}$ & $\begin{array}{c}\text { inexperienced } \\
\text { teachers }\end{array}$ \\
\hline $\begin{array}{l}\text { Looking for free } \\
\text { application and } \\
\text { learning individually }\end{array}$ & 58.33 & 50 \\
\hline $\begin{array}{l}\text { Looking for free } \\
\text { application and } \\
\text { learning from friends }\end{array}$ & 18.33 & 22.73 \\
\hline Using school website & 20 & 20.45 \\
\hline $\begin{array}{l}\text { Hand everything over } \\
\text { to teaching partner }\end{array}$ & 3.33 & 6.82 \\
\hline
\end{tabular}

Looking for free application and learning individually became the first choice of Indonesian biology teachers to improve their online learning management skills. It would be easier for experienced teacher to learn and manage online class individually because they were used to it. Interestingly, learning individually also became the first choice of inexperienced teachers. It showed that Indonesian biology teachers were highly motivated to learn and manage online learning. High internal motivation to learn new skills can make teacher participate in their professional development [6]. This finding also in line with Hung's that self-direction, motivation for learning and technological self-efficacy can make primary teacher ready for an online learning class.

Google Classroom was the most favorite application they choose (56\%) as it is served for free by Google; meanwhile, some of them (23\%) using WhatsApp Group, the familiar social media. The rest of respondents used other applications, such as Zoom, Quizizz, Quipper, Edmodo, school website, Facebook/Messenger, and some others.

Using Google Classroom as the most favorite Indonesian biology teachers in line with Sudarsana [11]. Google Classroom defined as one of the ways to deceive Indonesian technology-based education that has not been able to catch up with developing countries. This application also considered suitable in island country like Indonesia. However, teacher must consider that not all students have a laptop or android while it is an absolute condition of using Google Classroom as a teaching method.

Discovered difficulties from this study also showed that Indonesian biology teacher's willingness to learn should be appreciated. Starting from lack of experience, almost half of them $(49 \%)$ stated that there was no problem in organizing online classes. There were only $24 \%$ of application mastery constraints left; meanwhile others were related to student's control, mastery of subject and longer preparation time. These difficulties 
then classified into three categories, namely technology aspect, teacher aspect and student aspect.

Technology difficulty were related to the difficulty of mastering application. The low percentage of application mastery constraints left showed that motivation of most Indonesian biology teachers made them succeed to familiar with online learning application. However, the difficulties in operating the application used for online learning showed that those teachers needed to improve their skill of digital literacy [12]. It was because they were never interacted or unfamiliar with those applications.

Online learning difficulties from teacher perspective were less than $4 \%$ which related to the longer time needed for preparation. Indonesian biology teachers argued that materials preparation, assignment and its assessment, exam and its assessment needed a longer time than face-to-face learning. A longer time needed because teacher was transforming from face-toface into online learning. This transformation needed a habituation and it needed time. When teacher became familiar with the online learning environment and making an online learning preparation became a habit, preparation will no longer a difficulty.

Student aspects contributed the second biggest proportion of Indonesian biology online classes (17\%) after the difficulty of mastering application. This difficulty including students' presence, delayed in submitting assignments, students' control, students' activity and motivation. To solve these problems, teacher need a professional online learning management. Students' presence optimization could be reached by using three kinds of presence as described by Garrison et al [13]. One of them, namely social presence, could be maintained throughout the course when it given at the beginning of the online learning [14]. Although students' self-discipline is necessary for students' successful completion of online learning [6], teacher must consider an extra time for students' submitting assignment, especially for student who met the difficulties in the availability of data package and internet networks, even student who do not have any laptop or cellular phone [15]. Students' conditioning is one of the most difficult things in online learning management because it is affected with many factors, such as interference from family members that reduce learning concentration [15]. Thus, teacher must seek the most suitable way in students' conditioning because it will determine the enthusiasm and motivation.

Solving online learning difficulties need both teachers' perspective and students' perspective by use metacognitive strategy in their online class, start from learning preparation as well as learning evaluation [15]. Teacher must make student could access all information about the courses easily so that they could determine their progress along the online learning. Student could apply their goal setting, self-management about time management and evaluation strategy based on teacher explanation. Student must realize that they had to take full responsibility for their own learning, for example teacher could not urged them to keep reading so that they had to monitor their own learning progress. For time management, teacher could set up the due date for assignment submitting. Student would be aware and try to submit before the due date. For self-evaluation, teacher could announce that student with late submission would be reduced the score. However, teacher must give some exception for the late student who report for obvious reasons

Various learning activities were successfully managed by online classes starting from presenting materials to evaluation. Some of biology teachers (30\%) also managed practical work by online classes, whether using a virtual laboratory or simple practicum guidance to do at home.

\section{CONCLUSION}

Teacher's enthusiasm responses dominated the results of the questionnaire filling for both teachers with prior experience or teachers without prior experience, young and senior teachers, state school and private school teachers. It can be concluded that the efforts of biology teachers were able to conduct online learning during the Covid-19 pandemic. For papers published in translation journals, please give the English citation first, followed by the original foreign-language citation [6].

\section{REFERENCES}

[1] C. N. She, O. Farrell, J. Brunton, E. Costello, E. Donlon, S. Trevaskis, S. Eccles, "Teaching online is different: critical perspectives from the literature", Dublin: Dublin City University, pp 184, 2019.

[2] B. A. Trammell and C. LaForge, "Common Challenges for Instructors in Large Online Courses: Strategies to Mitigate Student and Instructir Frustation", Journal of Educators Online, vol. 14, no. 1, 2017.

[3] E. R. Sari, "Teacher professional development in an online learning community: a case study in Indonesia", Intercultural Education, vol. 23, no. 1, pp. 63-72, 2012.

[4] A. Abidah, H. N. Hidaayatullah, R. M. Simamora, D. Fehabutar, L. Mutakinati, "The Impact of Covid-19 to Indonesian Education and Its Relation to the Philosophy of Merdeka Belajar," SiPoSe, vol. 1, no. 1, pp. 38-49, 2020.

[5] Y. Pujilestari, "Dampak Positif Pembelajaran Online Dalam Sistem Pendidikan Indonesia Pasca Pandemi Covid-19," Adalah: Buletin Hukum dan Keadilan, vol. 4, no. 1, pp. 49-56, 2020.

[6] M. L. Hung, "Teacher Readiness for Online Learning: Scale Development and Teacher Perception," Computers \& Education 2015

[7] C. L. Maknun, "Internet Based Mathematics Learning: IS Indonesia Able to Put the Internet 
into Mathematics Classroom?", GSE Journal of Education, pp. 22-36, 2013.

[8] J. Misieng, J. Ramanair, S. Rethinsamy, "Measuring Teachers' Readiness to Use Technology: Pedagogical and Content Knowledge (TPACK) pilot study," Journal of IT in Asia, vol. 8, pp. 7-13, 2018.

[9] T. Teo, An Initial Development and Validation of a Digital Natives Assessment Scale (DNAS)," Computers \& Education, vol. 67, pp. 51-57, 2013.

[10] T. Teo, S. C. Tan, C. B. Lee, C. S. Chai, J. H. L. Koh, W. L. Chen, H. M. Cheah, "The SelfDirected Learning with Technology Scale (SDLTS) For Young Students: An Initial Development and Validation," Computers \& Education, vol. 55, no. 4, pp. 1764-1471, 2010.

[11] I. K. Sudarsana, I. B. M. A. Putra, I N. T. Astawa and I W. L. Yogantara, "The use of Google classroom in the learning process," J. Phys.: Conf. Ser., 1175 012165, pp. 1-5, 2019.
[12] A. E. P. Atmojo and A. Nugroho "EFL Classes Must Go Online! Teaching Activities and Challenges During COVID-19 Pandemic in Indonesia," Register Journal, vol. 13, no. 1, pp. 49-76, 2020.

[13] D. R. Garrison, T. Anderson, W. Archer, "Critical Inquiry in a Text-Based Environment: Computer Conferencing in Higher Education," The Internet and Higher Education, vol. 2, no. 2, pp. 87-105, 1999.

[14] X. Feng, J. Xie, Y. Liu Y, "Using the Community of Inquiry Framework to Scaffold Online Tutoring," The International Review of Research in Open and Distributed Learning, vol. 18, no. 2, 2017.

[15] Rasmitadila, R. R. Aliyyah, R. Rahmatdtullah, A. Samsudin, E. Syaodih, M. Nurtanto, A. R. S. Tambunan, "The Perception of Primary School Teachers of Online Learning during the COVID19 Pandemic Period: A Case Study in Indonesia," Journal of Ethnic and Cultural Studies, vol. 7, no. 2, pp. 90-109, 2020. 